\title{
DZIAŁANIA KONSERWATORSKIE W RAMACH PROGRAMU "100 KAMIENIC" WE WROCŁAWIU NA PRZYKLADZIE OSIEDLA ROBOTNICZEGO PRZY UL. CHIŃSKIEJ
}

\begin{abstract}
Program 100 kamienic we Wrocławiu jest jedną z udanych prób rewitalizacji zabytkowej architektury na obszarze miasta Wrocławia. Architektura budynków mieszkalnych jest często traktowana utylitarnie i poddawana znacznym uproszczeniom w trakcie remontów i przebudów. Ważnym czynnikiem towarzyszącym rewaloryzacji budynków mieszkalnych są współczesne standardy określone przez przepisy techniczno-budowlane i oczekiwania mieszkańców. Wieloletnie zaniedbania uczyniły z atrakcyjnie położonych lokalizacji miejsca niechętnie uczęszczane przez mieszkańców. Problem uwidoczniły konieczne po powodzi w 1997 roku wyburzenia zaniedbanych budynków. Realizowany przez Zarząd Zasobu Komunalnego program kładł duży nacisk na zachowanie indywidualnej, zabytkowej architektury budynków mieszkalnych. Samorząd wrocławski dostrzegł straty wizerunkowe wynikające $\mathrm{z}$ niszczenia zabytkowych budynków i przeprowadził bezprecedensową akcję ich ratowania. Przykładem takiego podejścia do remontowanych obiektów są budynki mieszkalne stanowiące część osiedla robotniczego przy ul. Chińskiej we Wrocławiu, które zostały wyremontowane w 2008 r. Artykuł przedstawia proces ich rewitalizacji oraz zrealizowane $\mathrm{w}$ trakcie prac badania i ich wpływ na prace projektowe i budowlane.
\end{abstract}

Słowa kluczowe: rewitalizacja, ochrona zabytków, badania konserwatorskie, zabytkowe budynki mieszkalne, zasoby komunalne

\section{Znaczenia i założenia programu „100 kamienic”}

\subsection{Wstęp}

Zabytkowa architektura pochodząca z XIX i pierwszej połowy XX wieku, licznie reprezentowana przez budynki mieszkalne (kamienice czynszowe) dopie-

${ }^{1}$ Anna Małachowicz, Politechnika Wrocławska, Katedra Urbanistyki i Procesów Osadniczych, ul. Bolesława Prusa 53/55, 50-317 Wrocław; tel.: 71320 6339; e-mail: aniamalachowicz@interia.pl 
ro nie dawno znalazła się w centrum zainteresowania służb konserwatorskich i historyków sztuki.

Zaniedbane wrocławskie kamienice, często zasiedlone przez lokatorów komunalnych, pomimo centralnej lokalizacji, nie są uznawane za atrakcyjne miejsce zamieszkania. Koszt odnowy zdobnych, sztukateryjnych elewacji, rzeźbionych klatek, indywidualnej stolarki itd. przekracza możliwości finansowe użytkowników. Po powodzi w 1997 roku liczne kamienice zostały wyburzone.

Dążąc do zatrzymania degradacji zabudowy w centrum i pogarszania się wizerunku miasta Gmina Wrocław zaczęła w 2005 roku realizować programy wspierania remontów kamienic.

Program 100 kamienic był realizowany we Wrocławiu w latach 2006 2010. Założeniem programu było wspieranie remontów zabytkowych budynków mieszkalnych administrowanych przez Zarząd Zasobu Komunalnego we Wrocławiu. W pierwszym roku zostało wyremontowane 7 budynków, w roku 2008 34; w 2009 - 42, a w 2010 - 26 [4]. Od 2011 roku został zastąpiony przez program Rewitalizacji Wrocławskich Kamienic.

Celem artykułu jest prezentacja doświadczeń związanych $\mathrm{z}$ remontem i przebudową zabytkowych budynków przy ul. Chińskiej we Wrocławiu realizowanych w ramach tego programu.

\subsection{Problematyka rewitalizacji zasobu komunalnego we Wrocławiu}

We Wrocławiu, podobnie jak w innych miastach ,ziem odzyskanych”, spora ilość nieruchomości w obrębie Śródmieścia stanowi własność Gminy Wrocław i mieści mieszkania komunalne lub socjalne. $\mathrm{Z}$ około 7000 zachowanych kamienic czynszowych ok. 1700 stanowi własność komunalną [3].

Znaczna część tych budynków wymaga gruntownych remontów. Wieloletnie zaniedbania i samowola mieszkańców doprowadziły do zniszczenia części wspólnych (klatek schodowych, elewacji, poddaszy) oraz bardzo złego stanu instalacji wewnętrznych.

Od początku XX wieku zmienił się także standard wymagany dla mieszkań indywidualnych - budynki przy ul. Chińskiej posiadały wspólne dla 2 mieszkań toalety dostępne ze spoczników klatki schodowej a także klatki schodowe i stropy międzykondygnacyjne $\mathrm{z}$ materiałów palnych. Problemem były też nieocieplone ściany zewnętrzne i połacie dachowe.

Ze względu na brak lokali zastępczych prace budowlane w większości rewaloryzowanych budynków musiały być prowadzone bez wysiedlania mieszkańców. 


\section{Osiedle na Brochowie}

\subsection{Historia osiedla}

Rozwój Brochowa jest związany z rozwojem kolei. Gdy w roku 1845 powstała stacje kolejowa wieś Brochów liczy 399 mieszkańców. W 1896 r. powstała na tym obszarze stacja rozrządowa.

Na początku XX wieku na Brochowie powstały 3 osiedla w zabudowie wielorodzinnej i dzielnica willowa. Zbudowano ratusz (1908 r.), wieżę ciśnień (1903 r.), szkołę i dwa kościoły (katolicki i ewangelicki, oba w 1911 r.). Osiedle przy dzisiejszej ulicy Chińskiej zostało ukończone w 1914 roku.

Podczas przeprowadzonej kwerendy archiwalnej w Archiwum Budowlanym i Archiwum Państwowym we Wrocławiu nie odnaleziono dokumentacji kamienic.

Zespół osiedla na Brochowie jest wzmiankowany w publikacjach min. w: Kempter, "SiedlungundStadtplanungs in Schlesien", t.1. [1, 5].

\subsection{Budynki Chińska 2B, 2C, 3A, 6A i 6B}

Budynki Chińska 2B, 3A, 6A i 6B stanowią warianty jednego projektu budynku trzytraktowego i dwupasmowego o 3 kondygnacjach naziemnych, poddaszu nieużytkowym i piwnicy, zwieńczonego dwuspadowym dachem z naczółkiem.

Budynki są zestawione bliźniaczo. Na styku dwóch budynków znajduje się szyb doświetlający i wentylujący klatkę schodową oraz pomieszczenia ustępowe. W elewacji bocznej - szczytowej znajduje się jedna oś okienna i centralnie umieszczone wejście do budynku (rys. 1-2).

Symetryczne elewacje wzdłuż ulicy mają po osiem osi okiennych i dwa balkony. Budynki posiadają cokół z cegły klinkierowej - wiśniówki, ceglane obramienia otworów i gzymsy międzykondygnacyjne. Poniżej gzymsu wyeksponowano szachulcową konstrukcję ścianki kolankowej i końcówki belek stropowych.

Elementem wyróżniającym poszczególne budynki było malowanie płaszczyzn tynkowanych i konstrukcji szachulcowej oraz płyciny w elewacjach szczytowych. Budynek Chińska $2 \mathrm{C}$ stanowi drugi typ budynku występujący na osiedlu.

Także w zabudowie bliźniaczej, posiada 5 kondygnacji naziemnych w części frontowej i $4 \mathrm{w}$ części tylnej. W ścianach zewnętrznych poddasza wyeksponowano konstrukcję szachulcową. Detal ceramiczny i ślusarski jak w budynkach pierwszego typu. 


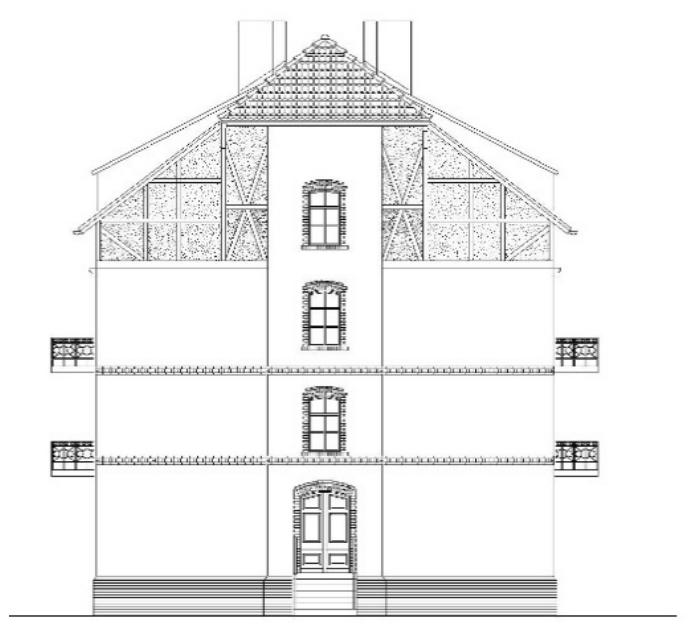

Rys. 1. Elewacja szczytowa budynku Chińska 3A, rys. autor Fig. 1. The elevation of the building of the Chinese street $3 \mathrm{~A}$

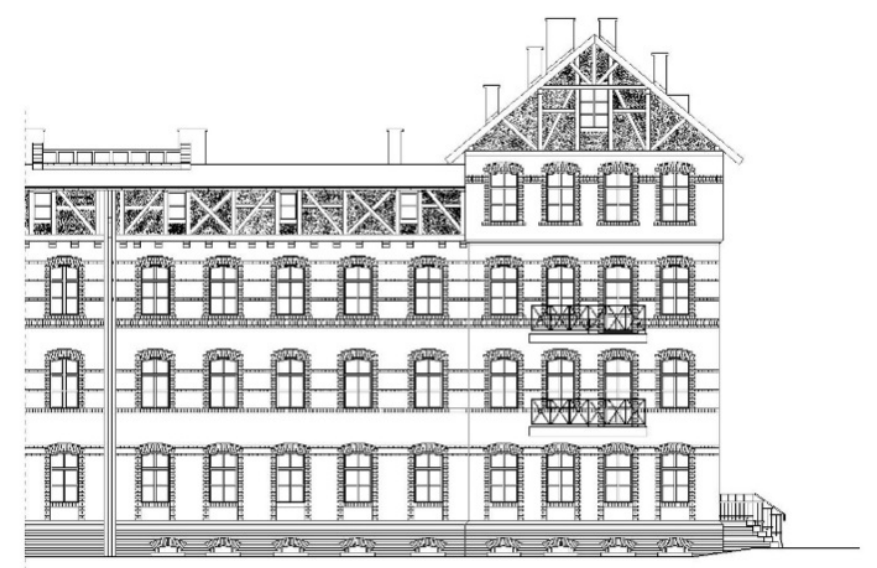

Rys. 2. Elewacja boczna budynku Chińska 2C, rys. autor

Fig. 2. Side elevation of the building of the Chinese street $2 \mathrm{C}$

\section{Projekt i badania konserwatorskie}

\subsection{Badania kolorystyki elewacji}

Przed wykonaniem projektu elewacji wykonano badania kolorystyki. W ich wyniku ujawniono, że na elewacjach zachowały się w znacznym stopniu fragmenty oryginalnego malowania z 1914 roku, prawdopodobnie z użyciem farb firmy KEIM. 
Badania ujawniły nie tylko pierwotne malowanie elewacji, ale też elementy związane z użytkowaniem budynku, jak malowany szyld w kolorze czarnym na budynku $2 \mathrm{~B}$.

Badane budynki były malowane z użyciem tych samych barw, choć poszczególne obiekty posiadały indywidualna kompozycję np. budynek $2 \mathrm{C}$ był pomalowany na kolor żółty ugier, 2B miał parter w kolorze niebieskim, a piętra w kolorze żółty ugier, 3A posiadał parter w kolorze ugru i piętra niebieskie, a budynki 6A i B miały ściany malowane na kolor gołąbkowo szary. Dodatkowym urozmaiceniem ścian były geometryczne płyciny z tynku fakturalnego (baranek). Kolejnym elementem urozmaicającym kolorystykę osiedla były malowania konstrukcji szachulcowej na kolor czerwony (2C) lub zielony (2B, $3 \mathrm{~A}$, 6A i 6B). Balustrady balkonów i schodów zewnętrznych były malowane na kolor ciemno zielony [2]. Wyniki badań zostały uwzględnione w projekcie elewacji.

\subsection{Termomodernizacja elewacji}

Ze względu na geometrię okapu i klinkierowe detale elewacji pełne ocieplenie ścian zewnętrznych nie było możliwe. Aby podnieść izolacyjność ścian zaprojektowano ocieplenie $\mathrm{w}$ formie tynków termoizolacyjnych perlitowych grubości $3 \mathrm{~cm}$ $\mathrm{z}$ zewnętrzną wyprawą z tynków o fakturze zgodnej z pierwotnym projektem (tynki gładkie lub w płycinach „,baranek”).

Zaprojektowano nową stolarkę okienną drewnianą (szkloną szybą zespoloną o współczynniku przenikania ciepła $1,1 \mathrm{~W} / \mathrm{m}^{2}$ ) z odtworzeniem dekoracji słupka i ślemienia.

Połacie dachowe i ściany szybu przy klatce schodowej zostały ocieplone wełną mineralną i styropianem. Przeszklenie szybu wymieniono na płyty poliwęglanowe kanałowe 5-cio komorowe $16 \mathrm{~mm}$, bezbarwne. Instalacja grzewcza nie była przedmiotem opracowania.

\subsection{Dostosowanie budynków do obowiązujących przepisów techniczno-budowlanych}

Projekt obejmował nie tylko działania konserwatorskie. Zdecydowano o likwidacji toalet na półpiętrach i wykonaniu łazienek indywidualnych dla każdego lokalu. Wymieniono piony instalacyjne. Wykonano nowe przewody wentylacyjne w mieszkaniach.

Niektóre elementy nie mogły być dostosowane do dzisiejszych wymogów. Konieczne okazało się uzyskanie odstępstwa od obowiązujących przepisów przeciwpożarowych w zakresie: długości dróg ewakuacyjnych.

Ze względu na zakres prac, realizowanych bez wysiedlania mieszkańców, stropy pod projektowane pomieszczenia sanitarne zostały wzmocnione płytą ze zbrojonego betonu, jednak nie wymieniano stropów międzykondygnacyjnych drewnianych. Zachowano schody drewniane z oryginalną tralkową balustradą. 


\section{Podsumowanie}

Pokazany w artykule przykład to kilka z ponad stu realizacji remontów zabytkowych budynków mieszkalnych wykonywanych we Wrocławiu na przestrzeni 4 lat. Program odniósł sukces i wyznaczył nowe standardy dla prac budowlanych związanych z utrzymaniem zabytkowych budynków mieszkalnych. Obecnie działania zmierzające do podniesienia komfortu mieszkańców i zachowania unikalnej zabudowy śródmieścia są kontynuowane przez spółkę Rewitalizacja Wrocławska z wykorzystaniem m.in. doświadczeń programu stu kamienic. Miasto regularnie rozwija ofertę programów pomocowych dla mieszkańców i użytkowników zabytkowych budynków np. w formie dotacji dla wspólnot mieszkaniowych, rewitalizację wnętrz kwartałów czy możliwość uzyskania środków z budżetu obywatelskiego (rys. 3.).

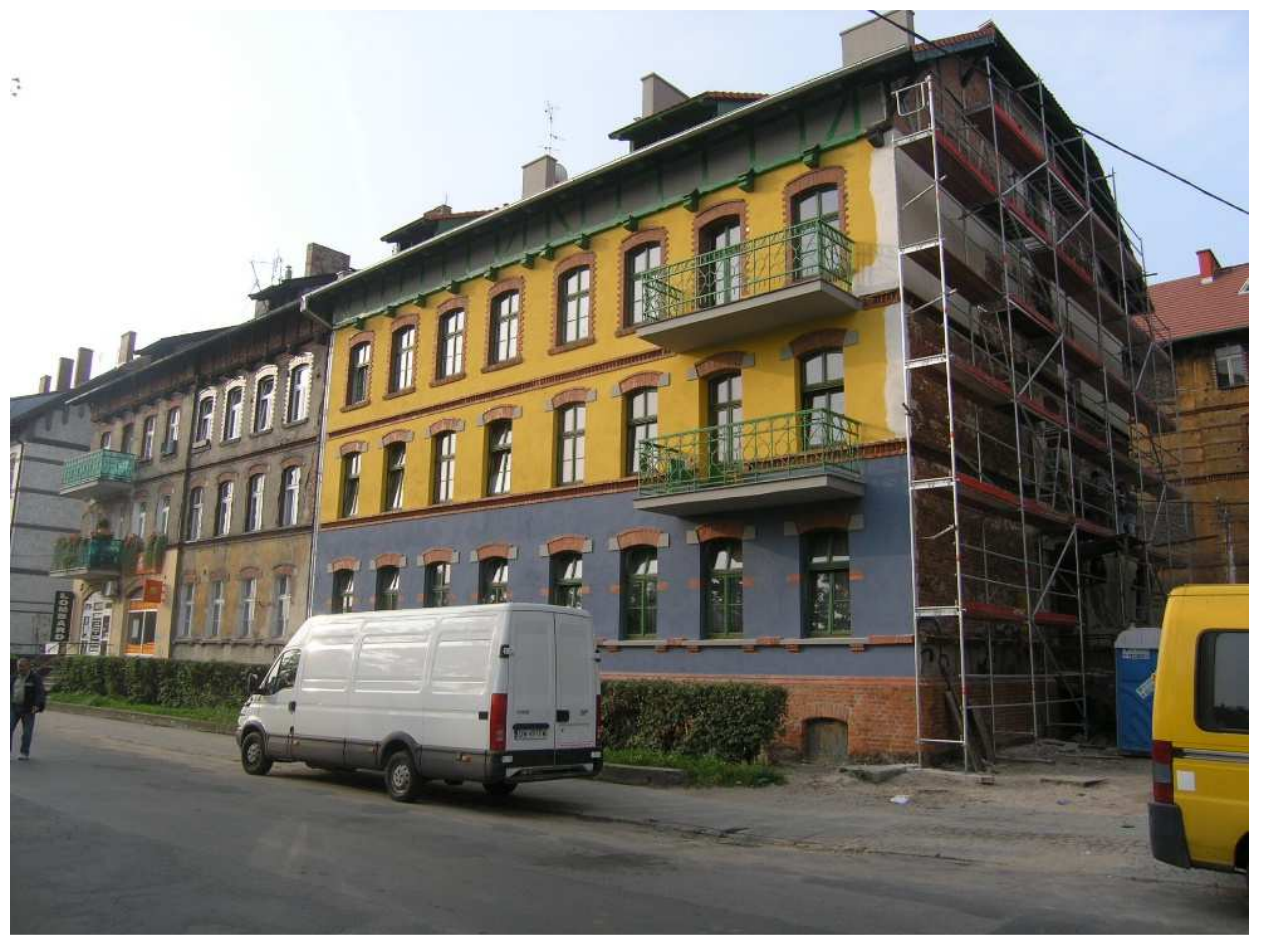

Rys. 3. Budynek Chińska 3A w trakcie prac, w głębi budynek 3B w stanie jak budynek 3A przed podjęciem prac, fot. autor

Fig. 3. Building Chinese street 3A during works, in deep the building 3B in the state like 3A building before work 


\section{Literatura}

[1] Encyklopedia Wrocławia, red. Harasimowicz J., Wydawnictwo dolnośląskie, Wrocław 2006

[2] „Wyniki badań kolorystyki elewacji zespołu budynków Chińska 2b, 2c, 3a, 6a,b we Wrocławiu" M. Małachowicz, A. Małachowicz, E. Małachowicz, marzec 2007 /msp/

[3] Żak Z.: Programy rewaloryzacji kamienic w: Leksykon architektury Wrocławia, Wrocław 2011

[4] www.zzk.wroc.pl (dostęp 24.05.2017 r.)

[5] http://pl.wikipedia.org/wiki/Brochow_(Wroclaw) (dostęp 07.06.2017 r.)

\section{PRESERVATION WORKS WITHIN THE "100 KAMIENIC" (100 TENEMENT HOUSES) PROGRAM IN WROCŁAW ON THE EXAMPLE OF THE WORKER'S ESTATE AT CHIŃSKA STREET}

\section{S u m m a r y}

Program „100 kamienic” (100 tenement houses) in Wrocław is one of the successful attempts of storical architectures revitalization. The architecture of residential buildings is often treated utilitarian and subjected to considerable simplification during renovation and reconstruction. An important factor accompanying the revitalization of residential buildings are the modern standards set by the law (technical regulations) and the expectations of residents. Long-term negligence has made the attractive place reluctantly attended by the locals. The problem emerged after the 1997 floods demolished neglected buildings.

Realized by Zarząd Zasobu Komunalnego program put a lot of emphasis on preserving the individual, historic architecture of residential buildings. Wroclaw self-government saw the losses resulting from the destruction of historic buildings and carried out an unprecedented rescue action. An example of such an approach to refurbished buildings are residential buildings forming part of the workers' settlement at Chińska street in Wroclaw, which was renovated in 2008. The article presents the process of their revitalization and the work carried out during the research and their impact on the design and construction work.

Keywords:Revitalization, monument protection, conservation research, historic residential buildings, municipal resources

Przestano do redakcji: 09.06.2017 r..

Przyjęto do druku: 01.09.2017 r. 
